\title{
Archival description using UNIMARC: Presidential Library experience
}

\author{
Opis arhivskega gradiva z uporabo formata UNIMARC na primeru \\ Predsedniške knjižnice v Sankt Peterburgu
}

\section{Olga Zhlobinskaya ${ }^{1}$}

ABSTRACT: The paper presents basic approaches to managing archival resources in the Presidential library (Saint-Petersburg, Russia). All resources in the collection are described using the RUSMARC format (national implementation of UNIMARC), which provides sufficient instruments to keep the hierarchical structure of archival description and to give detailed characteristics of the materials. The workflow of creating RUSMARC records for archives is presented in detail, including description from the general to the specific, using only level-appropriate data to avoid redundancy, creating name access points, indexing with Library Bibliographic Classification class numbers and subject headings according to the policy developed by the Presidential Library. Enhanced users' search interface is also presented; it includes both traditional library and archival resources with specific options for each type of resource. The conclusion is made that co-existence of both types of resources in the library catalogue using RUSMARC (UNIMARC) made the catalogue more efficient and user-friendly.

KEYWORDS: Presidential Library, archival resources, cataloguing, bibliographic description, RUSMARC, UNIMARC, access points, search interface

IZVLEČEK: Članek predstavlja osnovne pristope k upravljanju arhivskih virov v Predsedniški knjižnici (St. Peterburg, Rusija). Vsi viri v knjižnični zbirki so opisani z uporabo formata RUSMARC (nacionalna različica UNIMARC-a), ki zagotavlja dovolj možnosti za ohranitev hierarhične strukture pri opisu arhivskega gradiva in omogoča navedbo podrobnih značilnosti gradiva. Podrobno je predstavljen potek dela pri kreiranju zapisov RUSMARC za arhivske vire, vključno $z$ opisom od splošnega $k$ specifičnemu ob uporabi zgolj podatkov, ki ustrezajo posameznemu nivoju, da bi se s tem izognili nepotrebnim podatkom, ter s kreiranjem točk dostopa za imena, indeksiranjem na osnovi klasifikacijskih številk Knjižnične bibliografske klasifikacije (Library Bibliographic Classification) in predmetnih oznak v skladu s politiko, ki jo je oblikovala Predsedniška knjižnica. Predstavljen je tudi izboljšani uporabniški vmesnik za iskanje, ki vključuje tako običajne knjižnične vire kot tudi arhivske vire z možnostmi, specifičnimi za vsakega od obeh skupin virov. Zaključek je, da je zaradi vključenosti obeh skupin virov v knjižničnem katalogu na osnovi uporabe formata RUSMARC (UNIMARC) katalog učinkovitejši in uporabniku prijaznejši.

KLJUČNE BESEDE: Predsedniška knjižnica, arhivski viri, katalogizacija, bibliografski opis, RUSMARC, UNIMARC, točke dostopa, iskalni vmesniki

The article is based on the presentation at the 5th UNIMARC Users' Group Meeting, 17-18 November 2018, National Library and Archives of Iran, Tehran.

${ }^{1}$ Olga Zhlobinskaya, Presidential Library, Saint-Petersburg, Russia, zglobinskaya@prlib.ru. 


\section{Introduction}

The Presidential Library in Saint-Petersburg, one of Russia's three national libraries, was established in 2009 as a nationwide repository of digital materials either born-digital or digitized copies of the most important documents on the history, theory and practice of Russian statehood and Russian language.

The first library collection was based on digitized materials of the Russian State Historical Archive. The main sources of acquisition are state and regional archives (including the Russian State Historical Archive (RGIA), State Archive of Russian Federation (GARF), Leningrad Regional State Archive in Vyborg, Archive of Foreign Policy of the Russian Empire, etc.), national libraries and major research libraries of the country. The Presidential Library works in cooperation with regional libraries and research institutions in Russia and abroad, the Directorate for Navigation and Oceanography of the Russian Federation Defence Ministry, the Russian Geographical Society, other non-profit organizations and private collections. At the end of 2019, our collection included about 830000 items, and more than half of the collection are archival materials.

All the materials in the collection are described in the RUSMARC format, which was developed as a national implementation of UNIMARC considering the specifics of national practice and some differences existing between ISBD and Russian Cataloguing Rules (Skvortsov and Zhlobinskaya, 2018).

Since most of the Presidential Library collection consists of archival materials, one of the most important tasks to be solved from the very beginning of the library was the description of such materials. How to describe them? And how to manage archival records - keep a separate catalogue or include the archives into the integrated library catalogue along with all other types of materials? It is evident that archival and library materials are quite similar by nature in that they document human history. But due to different traditions, standards and description practices, archival materials are often not listed in library catalogues. On the other hand, we supposed that the inclusion of archival catalogue records into the integrated online catalogue could enable users to locate archival resources more easily.

\section{Designing description for archival resources in RUSMARC}

In 2010, the Presidential Library established a working group to develop the principles and approaches to integrated presentation and access to library, archival and museum resources in compliance with modern international standards. The Working Group included representatives from major libraries and archives of the country (Presidential Library, National Library of Russia, Russian State Library, Russian State Historical Archive, State Archive of Russian Federation), National RUSMARC Service, National Library Information Centre "LIBNET", library and archival software vendors (DIT-M, AS Company, Alt-Soft Company). The main objectives of the Working Group were:

- to analyse national and world practice of archival description as well as international standards and machine-readable formats in the field;

- to define data elements for different levels of archival description (fonds - series - file - item);

- to develop specific requirements for archival description in the library; 
- and finally, if necessary, to develop appropriate updates to the RUSMARC format for archives.

The Working Group studied major international standards used by archives. Three of them General International Standard Archival Description (ISAD (G)) (Zhabko ed., 2011b), ISAAR (CPF): International Standard Archival Authority Record for Corporate Bodies, Persons and Families (Zhabko ed., 2011a), and Encoded Archival Description (EAD) Tag Library (version 2002) (Zhabko ed., 2011c) were translated by the Presidential Library and published in Russian for local users. On the national level we did not have (and still do not have) a national standard for archives, just recommendations and general regulations issued by the Federal Archival Agency, and thus, the practice used in the country might vary from one archive to another.

The major standards used in libraries are ISBD (in Russia - Russian Cataloguing Rules and national standard for bibliographic description GOST R 7.0.100-2018) and MARC formats. MARC formats were not supposed to be used for archives and in general they do not allow to create detailed archival description but nevertheless they still can be used for specific purposes.

Most researchers note that unlike a bibliographic record, which usually focuses on an individual manifestation of a published work, an archival description is highly hierarchical and typically it involves a complex group of interrelated unique materials whose shared provenance and hierarchical arrangement must be shown very clearly. A MARC record, which gives a horizontal view of the object is not the best instrument to describe archives. But in fact, UNIMARC users are lucky because UNIMARC and UNIMARC-based formats have the mechanism for building comprehensive multilevel descriptions and establishing links between different levels.

A comparative study of RUSMARC (UNIMARC) and ISAD(G) showed that UNIMARC lacked some data elements which were essential for archives (Zhlobinskaya et al., 2013). Based on the results of the Working Group activities, in 2012 National RUSMARC Service and the Presidential Library submitted proposals to the IFLA Permanent UNIMARC Committee (PUC) to make changes and additions in UNIMARC, which we supposed to be necessary to present archives. After discussion, most of these proposals were approved by PUC, and later similar updates were made in RUSMARC. Also, a draft of the Guidelines for Archives (further Guidelines), in UNIMARC was developed, which is in the phase of finalising.

\section{General principles of archival description in UNIMARC}

The draft of the Guidelines gives the principles of using UNIMARC in presenting archival materials, lists data elements that could be commonly included in the description of archives and indicates where each data element would be placed in a UNIMARC record. Section 4 gives examples of full records for archives. Appendix A contains the Table of correspondence of EAD elements/attributes and UNIMARC, which includes the most significant EAD elements mapped to UNIMARC fields. General principles documented in these Guidelines are type of control, multilevel description and dates.

\subsection{Type of control}

First of all, when archival descriptions are incorporated into library catalogues, it is necessary to specify that this particular record describes archival material rather than traditional library 
resources. This information would make it possible to implement different options of search, facet navigation and displaying search results to users. Materials might be defined as archival by the manner in which they are described, and here the most important is not the type of materials (text, photo, etc.) but the way in which materials are arranged, physically organised and handled by the custodian. Type of control is specified in the record label (character position 9), and code "a" (archival control) is defined as "a method of describing and handling materials wherein the focus is on the contextual relationships between the items and on their provenance, rather than on bibliographic detail".

\subsection{Multilevel description}

Archival description is normally presented in a highly hierarchical structure proceeding from general description to more specific descriptions of its components, the description of each part being linked to its higher unit.

In UNIMARC the whole hierarchy may be built using a mechanism for linking entries (group of fields 46X), and archival description can be constructed with any desired level of detail - it may be collection level, if it is sufficient, or it may be set of records for all desired levels. The hierarchical level is indicated in the record label, character position 8. Additionally, the position of each described unit within the hierarchy is identified explicitly - with field 251 Organization and Arrangement of Materials. Normally, standard terminology is used here fonds, series, file, item.

\subsection{Dates}

In ISAD(G) dates are considered to be one of the essential elements when describing archives; any description of an archival collection or a part of the collection should always include the date(s) when the documents in the collection (or part of the collection) were created. If any date is not known exactly, an estimated date is given, and this is indicated in the description.

Most rules for archival description recognize dates of the collection as a part of the title, and in a UNIMARC record, the dates may be entered into field 200 Title and Statement of Responsibility, subfields \$j (Inclusive dates) and \$k (Bulk dates). When the dates of creation are not considered as a part of the title, they may be written in the field $210 \$ d$ Date of publication, distribution, etc.

Dates are also given in coded form in field 100 General Processing Data, character positions 8-16.

These principles were taken as a foundation for archival description in the Presidential Library.

\section{Workflow of describing archive resources}

The workflow of describing archives is presented in the edition Metodicheskie rekomendatsii po katalogizatsii i indeksirovaniyu elektronnykh kopiy dokumentov (Guidelines for Cataloguing and Indexing digital copies of documents) published by the Presidential Library in 2014 (Zav'yalova et al., 2014). Description in the Presidential Library proceeds from the general to the specific, which corresponds to the basic principle of the Guidelines and, in general, to the basic theoretical principle of archival description, i.e. the principle of "respect des fonds". 
The process begins with the creation of a collection level for fonds. Then records are created for series, file(s), item(s) - depending on the level of details desired. Normally it would be the fonds-series-file chain. But when necessary, an item-level description may be created, or even a component part description. All records are linked with fields 46-. Though typically a UNIMARC record may include relationships from the higher level to the lower ones, in RUSMARC it is generally implemented to define upward relationships - from the lower hierarchical level to the higher level (e.g. article to journal relationship, or, in the case of archives - from file to series, or from series to fonds). General structure of multilevel archival description is shown in Figure 1.

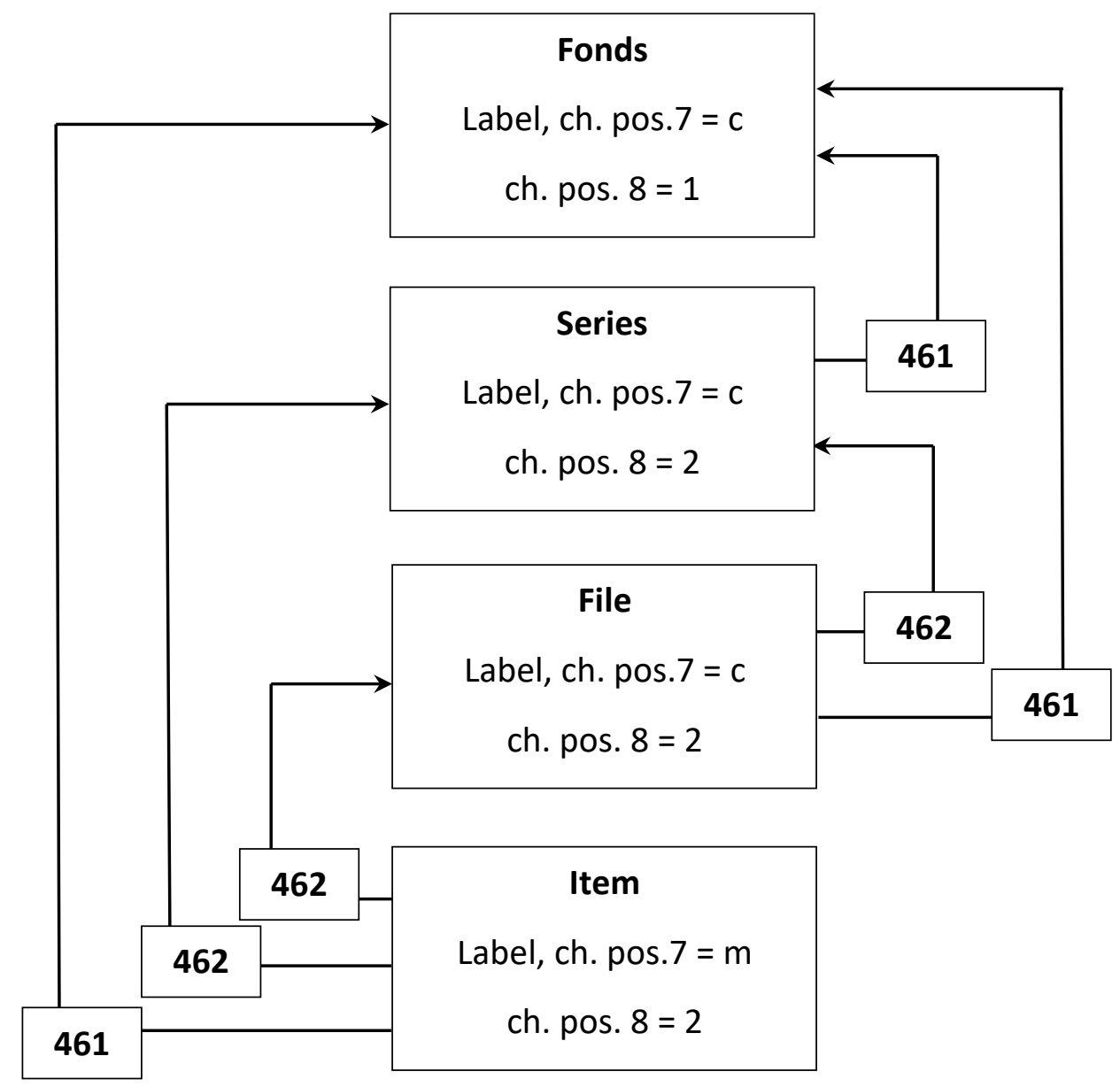

Figure 1: Multilevel archival description in RUSMARC (UNIMARC)

The basic set of data elements specified in the record label and hierarchical links used for different archival levels are given in Table 1. 
Table 1: Record label and links in archival description

\begin{tabular}{|c|c|c|c|c|}
\hline Data element & Fonds & Series & File & Item \\
\hline $\begin{array}{l}\text { Label, } \\
\text { ch. pos. } 6 \\
\text { (Type of record) }\end{array}$ & \multicolumn{4}{|c|}{$\begin{array}{l}\text { Basic type of material represented in the record, regardless of the } \\
\text { physical format (language materials, notated music, cartographic } \\
\text { material, etc. or multimedia) }\end{array}$} \\
\hline $\begin{array}{l}\text { Label, } \\
\text { ch. pos. } 7 \\
\text { (Bibliographic level) }\end{array}$ & $\begin{array}{l}\text { c } \\
\text { (collection) }\end{array}$ & $\begin{array}{l}\text { c } \\
\text { (collection) }\end{array}$ & $\begin{array}{l}\text { c } \\
\text { (collection) }\end{array}$ & $\begin{array}{l}\mathrm{m} \\
\text { monograph }\end{array}$ \\
\hline $\begin{array}{l}\text { Label, } \\
\text { ch. pos. } 8 \\
\text { (Hierarchical level) }\end{array}$ & $\begin{array}{l}1 \\
\text { (highest level } \\
\text { record) }\end{array}$ & $\begin{array}{l}2 \\
\text { (record below } \\
\text { highest level) }\end{array}$ & $\begin{array}{l}2 \\
\text { (record below } \\
\text { highest level) }\end{array}$ & $\begin{array}{l}2 \\
\text { (record below } \\
\text { highest level) }\end{array}$ \\
\hline $\begin{array}{l}\text { Label, } \\
\text { ch. pos. } 9 \\
\text { (Type of control) }\end{array}$ & \multicolumn{4}{|c|}{$\begin{array}{l}\text { a } \\
\text { (archival control) }\end{array}$} \\
\hline $\begin{array}{l}\text { Label, } \\
\text { ch. pos. } 18 \\
\text { (Descriptive } \\
\text { cataloguing form) }\end{array}$ & \multicolumn{4}{|c|}{$\begin{array}{l}x \\
\text { (ISBD provisions are not applicable to the type of resource) }\end{array}$} \\
\hline Links (hierarchical) & No & $\begin{array}{l}461 \\
\text { link to FONDS }\end{array}$ & $\begin{array}{l}461 \\
\text { link to FONDS } \\
462 \\
\text { link to SERIES }\end{array}$ & $\begin{array}{l}461 \\
\text { link to FONDS } \\
462 \\
\text { link to SERIES } \\
462 \\
\text { link to FILE }\end{array}$ \\
\hline
\end{tabular}

The type of material is specified in Label, ch. pos. 6. For archival fonds normally it would be code " $m$ " (multimedia); at the level of file and item the code value is determined depending of the main content of the unit, regardless of physical media. Thus, RGIA Fond 759 op. 91 d. 100 "Photographs and print portraits of historical persons of the 19th cent. - beginning of the 20th cent." consists of 95 portraits, so code value "k = two-dimensional graphics" is used.

Field 100 contains inclusive dates of the collection. Additionally dates may be given in field 122 when (a) the indication of dates in field 100 is insufficient and it is necessary to specify precise dates of the collection, or (b) inclusive dates in field 200 are given as separate spans of dates and/or dates separated with commas, if there is a significant gap in the chronological sequence of the materials of the collection). See examples:

EX 1:

Inclusive dates: January, 11950 - March, 311964

122 2\#\$ad19500101\$́ad19640331

EX 2:

Inclusive dates: 2003, 2006, 2010

122 1\#\$́ad2003\$ad2006\$ad2010 
EX 3:

Inclusive dates: 1917-1991, 2001

122 2\#\$ad1917\$ad1991

122 O\#ad2001

In general, an archival description may include any material-specific coded data fields depending on the type of material. E.g. for archival units comprising textual materials, field 101 Language of Resource is used to specify the language(s) used in the unit. If the archival item is a drawing or a photograph - coded data might be given in field 116 Coded Data Field: Graphics to make the description more precise and detailed.

To avoid redundancy of information, information that is common to all lower-level units must be present at the highest appropriate level. On the lower levels, only information appropriate for the level being described must be provided. As a result, elements like material-specific fields for photographs, maps, etc. would be used at item level, and in some cases at file level.

In block 2-- the following fields of descriptive information are used:

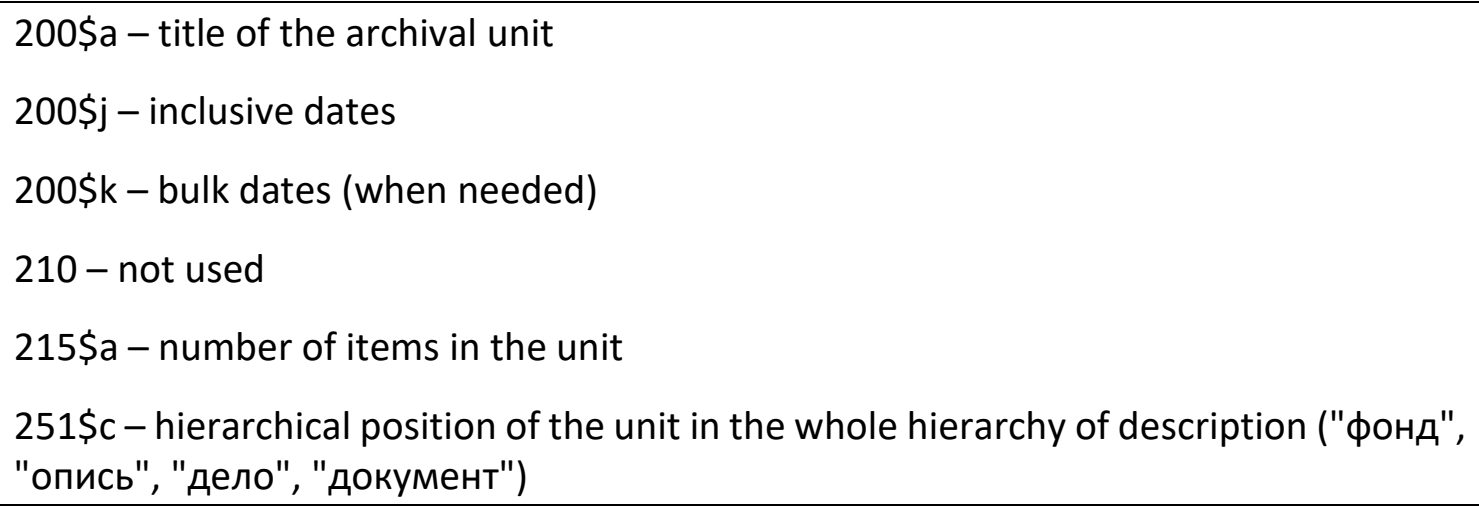

In block 3-- any note may be entered as applicable, e.g. note on former owners (field 317), any significant actions with the unit, including arrangement, appraisal, preservation, etc. (field 318), source of acquisition (field 345), conditions governing access and/or reproduction (field 371), textual description of the unit contents (field 330), etc.

Fields in block 4-- provide links to higher level records. Other fields may also be used as appropriate, e.g. field 464 for component parts of the archival item being described.

All access points (personal names, corporate names, family names, geographical names, subject headings) at any level of description are controlled with the authority files that are common for library and archival materials; it makes search results more complete and precise.

The name of the creator (person, corporate body or family) is given in field 7-0 (and 7-1, when there is more than one creator). Names of corporate bodies, persons, families having some other form of responsibility for the unit are given in other fields of block 7--. 
Every record at any hierarchical level is indexed with subject headings and class numbers (Library Bibliographic Classification) using the policy of indexing archival materials developed by the Presidential Library.

Example of the record:

\begin{tabular}{|c|c|}
\hline Label & 06822cmc2a2200000\#x\#450\# \\
\hline 001 & 6ca00cb3-0a74-4abc-96e7-999e3d90f730 \\
\hline 100 & \#\#\$a20150128|18401843k\#\#|Orusy0189\#\#\#\#ca \\
\hline 101 & 0\#\$ager \\
\hline 102 & $\# \# \$ a D E$ \\
\hline 120 & \#\#\$ab \\
\hline 121 & \#\#\$aa||aau\#a\# \\
\hline 123 & $1 \# \$ a a$ \\
\hline 124 & \#\#\$aa\$bd \\
\hline 200 & $\begin{array}{l}\text { 1\#\$аКарта Персии и Месопотамии, составлена К. Циммерманом\$ј1840- } \\
1843 \text { гг. }\end{array}$ \\
\hline 215 & \#\#\$а1 лист\$скарт.\$d62×48 см \\
\hline 251 & \#\#\$сДело \\
\hline 300 & $\begin{array}{l}\text { \#\#аЗаголовок на карте на немецком языке: West-Persien und } \\
\text { Mesopotamien. C. Ritters Erdkunde, Buch 3. West-Asien. Iranische Welt, } \\
\text { bearbeit von Carl Zimmermann, second Lieutenant im } 21 \text { Infanterie Regiment, } \\
\text { herausgegeben durch C. Ritter und F. A. O Etzel. Berlin, Verlag v. G. Reimer, } \\
\text { 1840-1843 }\end{array}$ \\
\hline 300 & \#\#\$аБумага. Тушь, карандаш, акварель \\
\hline 461 & 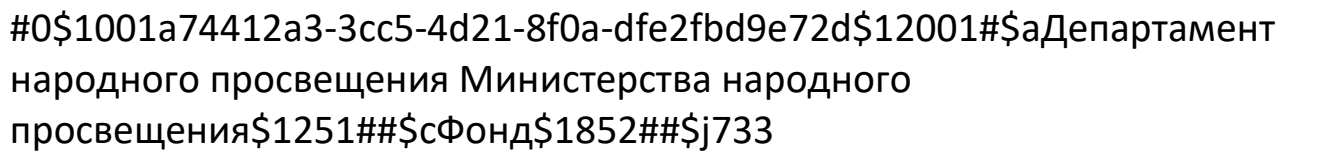 \\
\hline 462 & 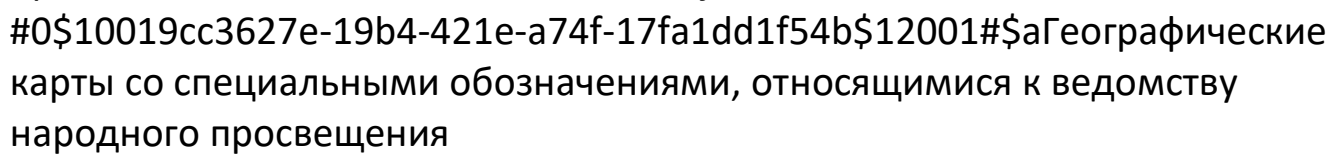 \\
\hline & \$vД. 73\$1251\#\#\$сОпись\$1852\#\#\$ј206 \\
\hline 607 & 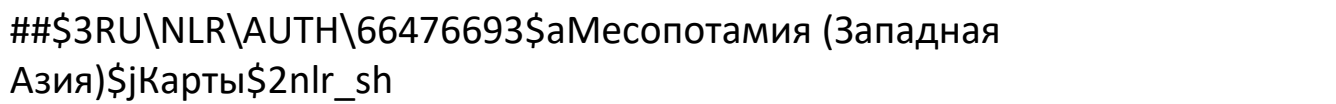 \\
\hline 607 & \#\#\$3RU\NLR\AUTH\6660241\$аИран\$јКарты\$2nlr_sh \\
\hline 617 & \#\#\$аИран\$2prlib_sh \\
\hline 617 & \#\#\$аИрак\$2prlib_sh \\
\hline 617 & \#\#\$аСирия\$2prlib_sh \\
\hline 608 & \#\#\$3DITM \AF\0000000386\$аГеографические карты\$2prlib_sh \\
\hline 686 & \#\#\$2rubbk\$a26.89(533.5)я64\$vLBC/M \\
\hline 686 & \#\#\$a26.17(533.5)\$vLBC/M\$2rubbk \\
\hline 686 & \#\#\$a26.89(5Ирн)я64\$vLBC/M\$2rubbk \\
\hline 686 & $\# \# \$ a 26.17(5 И p н) \$ v L B C / M \$ 2 r u b b k$ \\
\hline 801 & \#0\$aRU\$bPГИА\$c20150128 \\
\hline 801 & \#1\$aRU\$ьГлавНИВЦ\$c20150128\$2rusmarc \\
\hline 852 & \#\#\$аРГИА\$ј73 \\
\hline
\end{tabular}


Fond level records always include subject heading using the model "<creator name> -Archives" (field 600, 601 or 602). E.g. record for GARF F.R6991. Совет по делам религий при Совете министров (Сouncil for religious affairs under the Council of ministers of USSR) has the following subject heading: $60101 \$ a C C С \$$ Совет по делам религий\$јАрхивы (\$aUSSR $\$$ bCouncil for religious affairs\$jArchives).

At series level, the subject heading is always the topic, which is normally present in the title of the series. E.g. Opis' 7 of the above fond GARF R6991 is entitled "Личные дела высших служителей культа" (Personnel files of ministers of religion). The subject heading assigned to it is: 606 1\#\$аСлужители культа\$уCССР\$јЛичные дела (\$aClergy\$yUSSR\$jPersonnel files).

At file level, the main subject is defined depending on the content of items that are included in the file. Indexing at item level is type-specific. Here, the subject headings of any category may be used (name, topic, etc.).

For example: The record above describes a file from the fonds of Department of Education (RGIA. F. 733, op. 206, d.73). The file includes one document - a map of Persia and Mesopotamia.

The record above includes fields 120,121, 123 and 124 (material-specific data for maps), and it also is indexed with geographical subject headings (fields 607 and 617), form the subject heading (608) and the LBC class numbers.

The approach described above helped enhance the users' search interface. After conducting the search in the catalogue, the user may click a specific tab to choose a specific category of materials - library or archival material (Figure 2).

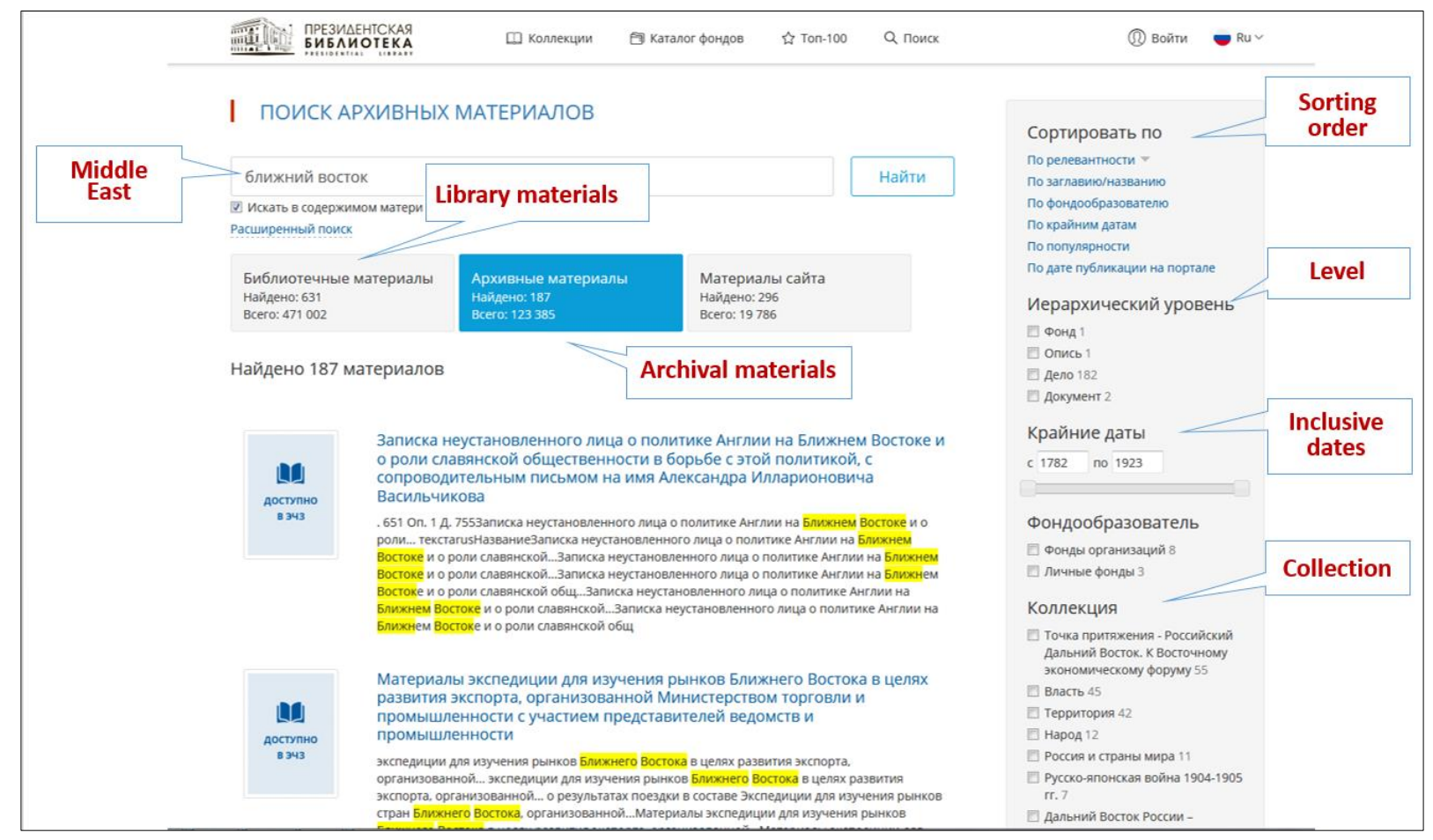

Figure 2: Search interface (Presidential Library, www.prlib.ru) 
Both library and archive materials have specific options to define the order of displaying retrieved records or to refine the search results. Archival records may be sorted by relevance, title, creator, inclusive dates, date of publication on the portal. Also, the user may choose to browse records at a specific archival level - fonds, series, file or item, may specify dates they are interested in, or browse materials included in a specific digital collection. Sorting and navigation options are given in the right-hand panel of the screen.

When viewing the selected record, the user may switch to another level.

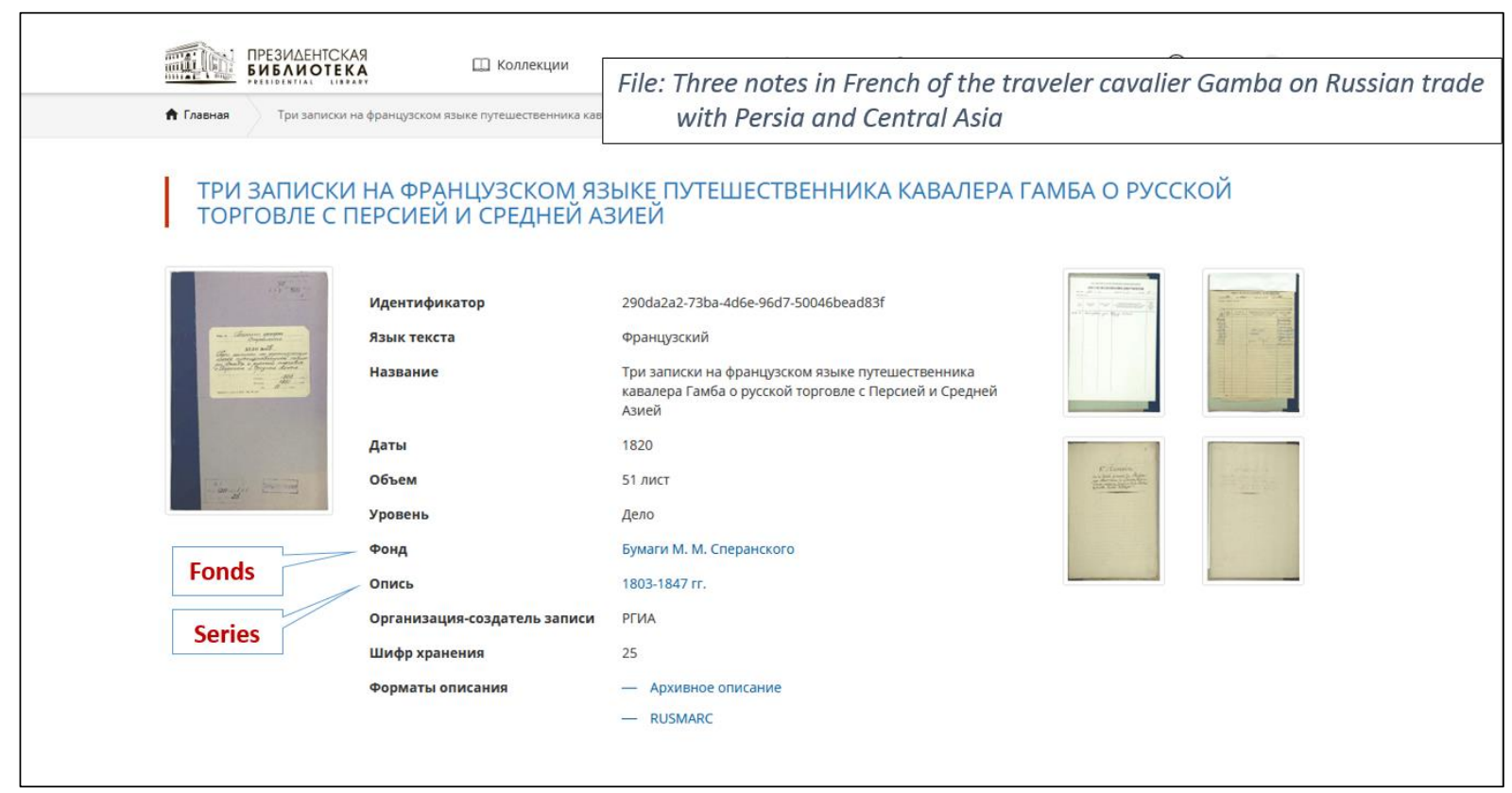

Figure 3: Display format (Presidential Library, www.prlib.ru)

For example, Figure 3 shows the record for the file "Three notes in French of the traveller cavalier Gamba on Russian trade with Persia and Central Asia". From this view, the user may switch to viewing the record for the series or fonds. In the example, you may see links to the series "1803-1847" and the fonds "Бумаги М. М. Сперанского" (Papers of М.M. Speransky).

Every archival record may be displayed in one of the following three formats: full format (with text representation of RUSMARC tags), archival format (brief record with archive-specific fields) and full RUSMARC record for professional users.

\section{Conclusion}

Using RUSMARC for describing archival materials, like other types of materials, made it possible to create the integrated catalogue of the Presidential Library, which, in turn, made user search most effective. Hierarchical links provided in RUSMARC (UNIMARC) help keep the hierarchical structure of archival description. On the other hand, the extensive set of coded data and note fields in RUSMARC help enrich the archival description to make it more precise. Archival and traditional library materials complement each other, and their co-existence in the library catalogue makes it more efficient and user-friendly. 


\section{References}

Skvortsov, V. and Zhlobinskaya, O., 2018. 20 years of RUSMARC. IFLA Metadata Newsletter, 4(2), 8-12. Available at:

https://www.ifla.org/files/assets/cataloguing/scatn/metadata_newsletter-20181217.pdf [09.01.2020].

Zav'yalova, L. et al., 2014. Metodicheskie rekomendatsii po katalogizatsii i indeksirovaniyu elektronnykh kopiy dokumentov [Guidelines for cataloguing and indexing digital copies of documents]. Sankt-Peterburg: Prezidentskaya biblioteka. Available at:

https://www.prlib.ru/item/343460 [09.01.2020].

Zhabko, E., ed., 2011a. ISAAR (CPF): Mezhdunarodnyi standart po sozdaniyu arkhivnykh avtoritetnykh zapisei dlya organizatsii, lits i semei [International Standard Archival Authority Record for Corporate Bodies, Persons and Families]. Sankt-Peterburg: Prezidentskaya biblioteka. Available at: https://www.prlib.ru/item/395178 [09.01.2020].

Zhabko, E., ed., 2011b. ISAD (G): Osnovnoi mezhdunarodnyi standart arkhivnogo opisaniya [ISAD(G): General International Standard Archival Description]. Sankt-Peterburg: Prezidentskaya biblioteka. Available at: https://www.prlib.ru/item/395179 [09.01.2020].

Zhabko, E., ed., 2011c. Kodirovannoe arkhivnoe opisanie (EAD). Biblioteka tegov. Versiya 2002. [Encoded Archival Description (EAD). Tag library. Version 2002]. Sankt-Peterburg: Prezidentskaya biblioteka. Available at: https://www.prlib.ru/item/417799 [09.01.2020].

Zhlobinskaya, O. et al., 2013. Printsipy i podkhody k sovmeshcheniyu predstavleniya i dostupa k bibliotechnym, arkhivnym i muzeinym resursam: sbornik nauchno-metodicheskikh materialov rabochei gruppy Prezidentskoi biblioteki [Principles and approaches to unification of presentation and access to library, archival and museum resources: a collection of methodological materials of the working group of the Presidential Library]. Sankt-Peterburg: Prezidentskaya biblioteka. Available at: https://www.prlib.ru/item/360874 [09.01.2020]. 